\title{
A Wide View of Democracy and An Inclusive Conception of The Social
}

Roberto Frega's Democracy Theory and Its Deweyan Legacy

\section{Torjus Midtgarden}

\section{(2) OpenEdition}

\section{Journals}

Electronic version

URL: http://journals.openedition.org/ejpap/1981

DOI: 10.4000/ejpap.1981

ISSN: 2036-4091

\section{Publisher}

Associazione Pragma

Electronic reference

Torjus Midtgarden, « A Wide View of Democracy and An Inclusive Conception of The Social », European Journal of Pragmatism and American Philosophy [Online], XII-1 | 2020, Online since 16 June 2020, connection on 26 June 2020. URL : http://journals.openedition.org/ejpap/1981 ; DOI : https://doi.org/ 10.4000/ejpap. 1981

This text was automatically generated on 26 June 2020.

\section{(c) (i) (9)}

Author retains copyright and grants the European Journal of Pragmatism and American Philosophy right of first publication with the work simultaneously licensed under a Creative Commons AttributionNonCommercial-NoDerivatives 4.0 International License. 


\section{A Wide View of Democracy and An Inclusive Conception of The Social}

Roberto Frega's Democracy Theory and Its Deweyan Legacy

Torjus Midtgarden

\section{Introduction}

1 Perspectives and resources from John Dewey and other classical pragmatists have been applied in contemporary political philosophy for some time. Yet Roberto Frega's Pragmatism and the Wide View of Democracy (2019) is to date the most comprehensive and ambitious attempt to draw on several such resources and to develop them within a systematic account of democracy. Frega not only applies Dewey's seminal conception of the public but also ontological perspectives drawn from Dewey and other pragmatists. Frega's book is a major achievement that deserves to be seriously considered and extensively discussed by everyone who thinks classical pragmatism has something to offer political philosophy. In this paper, however, I will only consider certain aspects of Frega's project that concern his use and development of resources from Dewey. Firstly, I consider how Frega updates and develops Dewey's wide conception of democracy. While Dewey famously explores the idea of democracy as a social ideal to be applied across institutional contexts, Frega develops a normative concept of democracy which is sociologically informed by social interactionism, construed broadly as encompassing classical sources, such as Dewey, George Herbert Mead and the Chicago school of sociology, as well as the more recent contributions of Ervin Goffman and Harold Garfinkel. Frega's approach follows Dewey in providing an account of democracy through considering immanent features of social life. I briefly point out that Frega's proposed distinction between ontological principles that generate and structurate social reality on the level of "habits," "patterns of interaction" and "forms of institutional organization" (2019: 90), parallells a similar distinction found in Dewey's social theory. However, Frega's further attempt (2019: 131) to base a pragmatist social ontology on Dewey's notion of association calls for more consideration and discussion. In particular, I show how this notion should be articulated in terms of Dewey's inclusive 
conceptualisation of the social ${ }^{1}$ - or the social taken as incorporating or integrating biophysical, technological, and psychological processes. This inclusive conception bears on Dewey's social and political theory through his considerations of human agency. Through an inclusive conceptualisation of the social, he sees human and social agents as involved in processes of production and consumption in which technologies and biophysical elements condition and inform their opportunities, dependencies and vulnerabilities. Notably, Dewey's inclusive conceptualisation of the social would conflict with the ways in which sociologists have conceptualised the social as sui generis, starting with Émile Durkheim (1982 [1895]). Following Anne Warfield Rawls' interpretation (1987, 2009), even Goffman and Garfinkel can be seen as committed to ways of conceptualising the social as sui generis. In building on Goffman's and Garfinkel's accounts, Frega's social interactionist approach, too, would be committed to a conceptualisation of the social as sui generis.

2 Turning to Frega's use Dewey's conception of the public, I further consider ontological underpinnings for this conception. While Frega suggests that Dewey's conception of the public could be supported by the Human Ecology of the Chicago school of sociology, I point out differences as well as commonalities between Dewey's social ontology and the Human Ecology as oulined by Robert Park and Ernest Burgess (1921) and later elaborated by Park (1936). Moreover, given that Dewey's conception of the public is based in a notion of "common affectedness" (Frega 2019: 188), I endeavour to show how the latter notion can be spelled out in terms of vulnerabilities and dependencies highlighted by Dewey's inclusive conceptualisation of the social.

Although in building on Goffmann and Garfinkel Frega would be committed to a conception of the social as sui generis, his use of Dewey's conception of the public further suggests that Dewey's inclusive conceptualisation would be relevant or even required. I therefore briefly suggest how Frega's pragmatist social ontology could be expanded by revisiting and requalifying his triadic distinction of ontological principles of social reality (habits, patterns of interaction, forms of institutional organisation) in the light of Dewey's inclusive conceptualisation of the social. Finally, I present two further reasons for considering Dewey's inclusive conceptualisation in spelling out a pragmatist ontology: firstly, it would be consistent with the naturalistic underpinnings of George Herbert Mead's social theory (1934); and, secondly, it could enhance the relevance of Frega's ontologically based theory of democracy in addressing current global challenges.

\section{Updating Dewey's Conception of Democracy and Developing Its Sociological Basis}

4 Preparing ground for his project Frega points out that "the distinctive feature of political pragmatism" lies in pragmatists' "original social-theoretic account of the constitutive features of a democratic society, of democracy as a form of society" (2019: 113). As Frega rightly suggests, this interpretation holds not only for thinkers we may think of as sociologists, such as Robert E. Park and George Herbert Mead, but also for John Dewey, the most influential political philosopher in the pragmatist tradition. In fact, as Frega makes clear, Dewey outlines elements of a social theory as a basis for his conception of democracy, perhaps most famously in Democracy and Education (DE). He here presents his wide conception of democracy as "more than a form of government" 
and as "primarily a mode of associated living, of conjoint communicated experience" (MW9: 93). To sustain his conception of democracy Dewey presents sociological perspectives stressing the centrality of communication for social reproduction of norms and ideals, as well as for socialisation. "Society not only continues to exist by transmission, by communication," Dewey thinks, "but it may fairly be said to exist in transmission, in communication" (MW9: 7). More specifically, Dewey analyses how individuals through communication may consent to plans of action, ${ }^{3}$ and also benefit from the community's fund of cultural and intellectual resources. ${ }^{4}$ While briefly suggesting the mechanism of perspective taking, which was later theoretically elaborated by George Herbert Mead (1934), ${ }^{5}$ Dewey's sociological perspectives on communication became a focal point for the Chicago school of sociology through Robert E. Park and Ernest Burgess' Introduction to the science of sociology (1921). ${ }^{6}$ In fact, by relating Dewey's brief analysis of communication to Émile Durkeim's concept of collective representations, Park and Burgess even suggest that Dewey's analysis may be "taken as a description of the process by which these collective representations come into existence" (1921: 38). Nevertheless, Dewey's analysis of communication in DE remains sketchy at best, and Park and the Chicago school never developed a full fledged (or consistent) theory of society. ${ }^{7}$ It is thus to be welcomed that Frega elaborates on this theoretically rich yet underdeveloped legacy of Park and Dewey. I will briefly focus on some aspects of Frega's development of this legacy.

In qualifying his approach to social ontology as "social interactionist" (2019: 89), Frega takes Dewey, Park and the early Chicago school as part of the same tradition, and he includes also the more recent contributions of Ervin Goffman and Harold Garfinkel. Through following leads of his theoretical predecessors, Frega wants to reconstruct patterns of social interaction of which the predicate "democratic" may be applied, and which further may serve as building blocks for extending the application of the predicate to "the largest possible domains of social life, from basic face-to-face interactions to formal political institutions" (2019: 78). As a theoretical strategy this approach could be seen as an updated elaboration of Dewey's efforts in $D E$ to develop a wide concept of democracy by extracting "desirable traits of forms of community life which actually exist" (MW9: 88-9). Like Dewey, Frega aims to establish a concept of democracy through considering immanent features of social life. Yet, tuned also toward contemporary political-theoretical distinctions, Frega goes on to reconstruct three major patterns or principles. Relational parity concerns interaction as symmetrical and not status-dependent; inclusive authority stresses that individuals are to be authors of the decisions whose consequences they will undergo; and social involvement refers to a social unit's capacity to involve its members in practices having in view some common good. ${ }^{8}$ Frega qualifies a concept of democracy based on these three principles as a "paradigm normative concept." ${ }^{\prime}$ Like philosophical projects that put emphasis on other master concepts, like justice or non-domination, he thus explores a concept of democracy that could, via empirical cues and examples, be applicable across various domains of social life, and not only in an institutionalised political sphere. In order to extend his application of the concept of democracy to such various domains, Frega (2019: 90) introduces an ontological division between three different levels or strata: "democratic habits"; "democratic patterns of interaction" (or democratic "collective habits"); and "democratic forms of institutional organization." To some extent, this division parallells Dewey's distinction in Lectures in China between habits, customs and institutions as "broad categories of human activity" (LC: 85 ) that are to provide criteria 
for normative assessment of how social arrangements contribute to "human welfare and freedom" (LC: 84). In this perspective, Frega may be seen to significantly update Dewey by drawing on Structuration Theory (Giddens 1984) and by taking the triadic division as principles that generate and structurate social reality so that the various levels are "in constant interaction and influence each other" (2019: 90). Yet, a transition to social ontology is in line with the Deweyan legacy and Frega (2019:131) in fact appeals to Dewey's ontological exploration of the notion of association. Nevertheless, this abstract strand of Dewey's social thought calls for more consideration and discussion, not only in the light of other interpretations that put emphasis on Dewey's concept of habit, like that of Italo Testa (2016). My concern is rather that Dewey develops his notion of association in ways that would not necessarily accord with ontological presuppositions of the social interactionist tradition in the broad sense at stake.

6 Dewey develops his notion of association in two steps. Firstly, as Frega points out, he defines the notion in an ontologically generalised sense. Association, Dewey thinks, is not a unique trait of humans and human societies: all other animate beings and all inanimate things are associated in the generalised sense in which both humans or " atoms and physical masses" are seen as "being acted upon by and affecting other things" (LW1: 138). Hence, "associated or conjoint behaviour" could be seen as "a universal characteristic of all existences" (LW3: 41). Secondly, however, Dewey goes on to qualify the category of human association in an inclusive sense. He thus aims to conceptualise ways in which social phenomena and processes may be taken to incorporate or integrate physical, technological, biological, as well as psychological processes (or "associations"). Rejecting various forms of reductionism, ${ }^{10}$ he endeavours to understand social phenomena in their "complexity" (LW3: 44) and to take "the social, in its human sense" as "the richest, fullest and most delicately subtle of any mode [of association] actually experienced" (LW3: 44). Sociologically, the inclusive conceptualisation supports consideration of how social organisation is conditioned and enabled by biological processes and by physical and technological infrastructures. ${ }^{11}$ Yet, Dewey's inclusive conceptualisation particularly matters for his social and political theory through considerations of human agency. As I return to below, through an inclusive conceptualisation, he sees human and social agents as involved in processes of production and consumption in which technologies and biophysical elements condition and inform their opportunities, dependencies and vulnerabilities. ${ }^{12}$

7 By considering and including biophysical processes and natural and technological infrastructures in his conceptualisation of the social, Dewey challenges conceptualisations of the social as sui generis in sociology. While the classical conceptualisation of the social as sui generis is found in Durkheim's work (1982 [1895]), there are other and more recent attempts that bear directly on Frega's project, such as those of Goffman and Garfinkel. Anne Warfield Rawls (1987) has pointed out how Goffman's outline of a theory of an interaction order is an attempt to conceptualise social order as sui generis. An interaction order in Goffman's sense involves interactional constraints that are not to be derived from an institutional order, nor from individuals or from aggregated effects or effects of routinization. An interaction order would thus be a distinct social entity sui generis. As Warfield Rawls has suggested more recently (2009), Garfinkel's concept of a "constitutional order" is a comparable effort to conceptualise social order. Hence, in building on Goffman's and Garfinkel's concepts of social order in developing his interactionist account of democracy, Frega would be 
committed to a conception of the social as sui generis. In so far, his approach would thus be equipped to account for social interaction without having to consider psychological and biophysical processes or technologies.

8 Nevertheless, Dewey's inclusive conceptualisation of the social would still be relevant for Frega's project. For example, in considering democracy as "a form of life" Frega notes that "[t]he notion of forms of life connects human experience with the larger space of nature," and that "[s]peaking of forms of life means challenging the boundaries that separate culture and nature, with the aim of making more visible the entanglement between these two dimensions" (2019: 57). However, Dewey's inclusive conceptualisation bears more profoundly on Frega's use of Dewey's concept of the public.

\section{The Public, Dewey's Inclusive Conceptualisation of The Social and Human Ecology}

Frega's project includes an account of democracy as social order but also "a theory of democracy as collective action" (2019: 65). In developing the latter, he employs Dewey's conception of the public, as well as other pragmatist approaches, to focus on various aspects of "democratic approaches to social problems" and on "the capacities and the conditions which enable and constrain forms of political activation" (2019: 159). Following Dewey's and other pragmatists' accounts, he sees collective activation as taking place when agents need to amend practices and institutions "in the face of changes in the social and natural environment" (2019: 160). As Frega makes clear, Dewey's concept of the public, which turns on "indirect consequences of transactions," focuses more specifically on "human affectedness, on the existence of a public as the collective body composed of all those who are affected" (2019: 188). While a public must become aware of its "common-affectedness" in order to come into existence, the constitution of a public is originally sparked by "the need to control the circumstances of social and natural life" (2019: 190). On this account, political institutions have thus arisen "against the background of the ecological sea changes which, by transforming relationships between individuals, human groups, and the environment, required new and more complex forms of organized action" (2019: 190). Frega proposes that the term "ecological" could be understood here in the sense of the Human Ecology of the Chicago school of sociology. ${ }^{13}$ Although Frega rightly suggests that both Dewey and the originators of the Human Ecology framework take steps to develop a naturalistic ontology, Dewey's social ontology and the Human Ecology as outlined by Robert Park and Ernest Burgess (1921), and later elaborated by Park (1936), have crucial differences, as well as commonalities. ${ }^{14}$ Let us consider differences before turning to commonalities.

10 Human Ecology would differ from Dewey's ontological outlook with regard to the conceptualisation of human agency. Elaborating on Darwin's notion of "the struggle for existence," Park and Burgess put emphasis on competition as "the elementary, universal, and fundamental form" of interaction (1921: 507). Competition for material resources and territory is construed as an unconscious biotic process between human individuals ${ }^{15}$ that determines their distribution in space and that underlies the economic organisation of society. Although competition would be constrained by "custom and consensus" in human societies (Park 1936: 13), Park conceives the individual as belonging to a "biotic substructure," as well as to a "cultural 
superstructure" (1936: 13). However, this idea of biotic processes of competition as the most basic level of human agency differs significantly from Dewey's understanding of human agency. Dewey's inclusive conceptualisation of the social does not isolate a biological dimension of human agency or privilege it over social or cultural dimensions, nor does it assume any direct link between biotic and economic processes in terms of "competition." His inclusive conceptualisation rather focuses on how human vulnerabilities and opportunities are biologically conditioned, as shown by childrens' immaturity and need of care and education, ${ }^{16}$ and by the need for adequate food. ${ }^{17}$ In particular, through processes of production and consumption, human opportunities, vulnerabilities and dependencies are conditioned and informed by technological artefacts and services and by access to natural resources. ${ }^{18}$ In a normative perspective, Dewey's emphasis on biologically and technologically conditioned vulnerabilities, as well as opportunities, contrasts sharply with Park's more direct and positive link between "the freedom of the individual" and competition as a biotic process (1936: 13).

11 Park's and Burgess' Human Ecology further suggests general conditions for political activation and action that both compares to and differs from Dewey's approach. In construing competition as the most fundamental form of human interaction, the human ecologist takes it to be the first stage in an ordered sequence of different forms of interaction. On this account, competition conditions and enables conflict conceived as a conscious of form of interaction and as a distinctively political process. "It is only in periods of crisis," Park and Burgess hold, "when men are making new and conscious efforts to control the conditions of their common life, that [...] competition is converted into conflict. It is in what has been described as the political process that society consciously deals with its crises [...]" (1921: 510). In fact, Dewey's approach in The Public and Its Problems (TPIP) tends to converge with Human Ecology on the assumption that political action arises from perceived problematic consequences of social, and in particular, economic activities. In fact, Dewey would agree with Park's and Burgess' suggestion that political action emerges from a perceived need to control conditions under which economic activities go on. ${ }^{19}$ Yet, again, Dewey's approach differs from that of Park and Burgess in seeing action consequences as problematic, not due to competing biotic agents and their "freedom," but rather as due to the vulnerability and affectedness of fullblown human agents. He provides examples of the affected public from the 1920s that succinctly bring out this point: child workers, women workers with no protection of their maternal health, workers with no old age pension or minimal wage, and farmers suffering from heavy mortgages and oscillating prices on farm products and agricultural implements..$^{20}$ As Dewey suggests in his lectures on social philosophy, ${ }^{21}$ understanding human vulnerabilities and ways of being affected requires consideration of natural and technological conditions for economic activities and for different modes of consumption in particular. Hence, human biological aptitudes and potentials, as well as land, natural resources, and vital technological infrastructures and services (such as electricity), must be included in the social and should further be seen as enabling conditions for human opportunities over which the polity needs sufficient control in order to provide for the affected public. ${ }^{22}$

12 Through the inclusion of land, natural resources, and technology in the conceptualisation of the social Dewey's social ontology becomes ecologically relevant, as suggested by Frega. In fact, Dewey sometimes considers the "ruthless exploitation of natural resources without reference to conservation for future users" (MW15: 262), as well as the "brutal exploitation of nature and man in times of peace" (LW2: 344). Yet, if 
we look for relevant sources of inspiration, Thorstein Veblen and his account of various modes of consumption should be considered, ${ }^{23}$ rather than the Human Ecology outlined by Park and Burgess. Nevertheless, Dewey's inclusive conceptualisation of the social and the Human Ecology of the Chicago school could be seen to share a general ontological orientation. In his later development of Human Ecology, Park takes pains to include not only population and biotic processes but "technological culture" and "the natural resources of the habitat" as constitutive elements of society, as well as "custom and beliefs" (or "non-material culture") (1936: 15). This conceptualisation of society thus broadly corresponds to basic elements in Dewey's inclusive definition of the social. By considering and including biophysical processes, natural resources and technology, both Dewey and Park challenge conceptualisations of the social as sui generis in sociology.

As pointed out above, in building on Goffman's and Garfinkel's concepts of social order, Frega would be committed to a conception of the social as sui generis. However, Frega's use of Dewey's conception of the public comes with a wider set of ontological commitments. Moreover, in view of Frega's expressed aim to develop a pragmatist social ontology inspired by Dewey's notion of association, I therefore revisit his ontological distinction between habits, patterns of interaction and forms of institutional organisation in the light of Dewey's inclusive conceptualisation of the social.

\section{A Pragmatist and Inclusive Social Ontology: Habits, Patterns of Interaction and Institutional Forms}

Suggesting his tripartite distinction as "principles that generate and structurate social reality" (2019: 86) Frega wants to take into account of how habits, patterns of interaction and forms of institutional organisation "are in constant interaction and influence each other, contributing together to shape social life" (2019: 90). As for the category of habit, however, it fits uneasily within an account of the social as sui generis. Already in American sociology in the 1920s the concept of habit was seen as "closely associated with psychology" and thus as jeopardising the autonomy of sociology - or it was rather taken belong to "the biological field" (Camic 1986: 1071-2). The tendency in sociology to reject this concept contrasts sharply with central role given to it in Human Nature and Conduct where Dewey aims to integrate biological perspectives, seeing habits as concretely embodied in involving "skill of sensory and motor organs" (MW15: 15) and as "requiring the cooperation of organism and environment" (MW14: 15). He further integrates sociological perspectives, conceiving "habits as social functions" (MW14: 15), as well as psychological perspectives, in stressing how reflective habits involve mental capacities and aptitudes through the work of imagination (MW14: 132-5). Frega subscribes to Dewey's account of habit as "an acquired predisposition to ways or modes of response" and as concerning "the patterns of interaction between an agent and his/her environment" (2019: 231). He further conceives habits in a Deweyan way as incorporating "perceptive, affective, and reflexive features" (2019: 230), taking their "reflective dimension" to be "operational and embodied" (2019: 230). More generally, he holds that "[t]he pragmatist human agent is an embodied social actor" (2019: 128). The underlying ontological commitments for using the concept of habit, however, can be articulated in terms of Dewey's inclusive conceptualisation of the 
social and would involve rejection of possible reconstructions (and reductions) of the concept in terms of the social sui generis.

As for the level of social interaction, we may further note how Dewey draws on biological and psychological perspectives in conceptualising conditions for human communication. While taking "[o]rganic and psycho-physical activities" as a condition for "the presence and operation of meanings" (LW1: 220), he sees sentience as "an indispensable means of any noetic function" (LW1: 199). Moreover, Dewey's stress on the role of sentience in human communication bears on his account of democracy and democratic processes. Notably, he thinks that emotional as well as intellectual consensus serves as a criterion for the moral rightness of a claim. ${ }^{24}$ More specificly, he takes "[t]he emotion of sympathy" to provide a basis for taking other persons' points of view and thus enabling consideration of "what justice demands in concrete cases" (LW7: 251). Sympathy further enables consideration of how "the welfare of all [is] affected by conduct" im-partial (LW7: 259). Dewey's stress on human sentience would be relevant for Frega's theory of democracy as well, in particular for his critical appropriation of Habermas. Frega finds that Habermas "focuses too much upon the linguistic dimension of discourses," while pragmatists "embody rationality in a thicker concept of experience which never loose sight of the deeper interdependencies of the mind with the body and with the outer world" (2019: 260-1). Again, however, an appreciation of Dewey's relevance could be further articulated and sustained through his inclusive conceptualisation of the social.

Finally, Dewey's inclusive conceptualisation would bear on the level of institutional organisation, as well as on the level of interaction, with regard to the role of technologies. In ways recalling Benedict Anderson's historical thesis of "imagined communities" (1991 [1983]), Dewey in TPIP considers how modern technologies and news media have enabled the sense of belonging to communities which extend far beyond face-to-face interactions. In industrialised nations, he observes, "[r]ailways, travel and transportation, commerce, the mails, telegraph and telephone, newspapers, create enough similarity of ideas and sentiments to keep the thing going as a whole, for they create interaction and interdependence" (LW2: 306). In other works he considers how new possibilities for sharing and discussing ideas "in areas of social concern" have been opened by new communication technologies (LC: 170). Moreover, he suggests that these possibilities could be developed on the model of international scientific forums for publishing and scrutinising knowledge claims. He thus projects an ideal public sphere which would be enabled and sustained by "the telephone, the telegraph, the radio, the transoceanic cables" (LC: 170) - and which may be sharply contrasted with prevailing practices in business and diplomacy of keeping information secret. ${ }^{25}$ Moreover, he speculates how people could contribute to a public fund of knowledge which "can be shared and increased at the same time" (LC: 178). Like scientific forums, such knowledge fund should not be organised through the imperatives and forces of the market, but would rather amount to a "socialism of knowledge" (LC: 178). Yet, he suggests elsewhere, such knowledge fund could enable political and democratic control of market forces and also sustain modes of production and consumption not subjected to these forces. ${ }^{26}$ Dewey's projected ideal could be interestingly compared to Frega's consideration of emerging economic practices of peer-production for creating and sustaining digital commons. Enabled by the internet these collaborative practices are, Frega points out, "expanding the scope of non-market and non-state models of 
production and consumption" (2019: 350), and they have democratising effects through "reducing impact of hierarchical mechanisms of coordination" and through "high levels of decentralization" (2019: 353). Hence, he thinks that "peer-production and knowledge commons create opportunities for a more democratic form of society right at the heart of its technological core" (2019: 352). Although digital commons would normally fall short of providing democratic control as conceived by Dewey, their ways of producing, storing and sharing knowledge of interest to members are comparable to Dewey's imagined knowledge fund. Moreover, while Dewey suggests that his knowledge fund could be sustained by transoceanic cables, telephones and radio receivers, digital commons are in fact enabled, structured and sustained by the technological infrastructure of the internet. More generally, by showing how communication technologies create new potentials for initiating and coordinating social action across national borders and for building and organising transnational communities, the example of digital commons suggests the relevance of Dewey's inclusive conceptualisation of the social. Considering also how digital commons involve modes of production and consumption that have emerged in response to prevailing forces of the market, Dewey's inclusive conceptualisation again proves relevant in stressing how human opportunities and vulnerabilities arise through modes of production and consumption and thus through technological dependencies. Hence, in emphasising the role of economic activities, Dewey's inclusive conceptualisation, along with Veblen's social thought, could provide a critical complementation of the social interactionist ontology developed in the earlier chapters of Frega's book.

\section{Concluding Remarks}

Frega's theory of democracy significantly develops and updates Dewey's conception of democracy in the context of 20th century sociology and contemporary political philosophy. His theory interestingly links up with ontological considerations in Dewey's and other pragmatists' work. Yet, as suggested by his use of Dewey's conception of the public in particular, a pragmatist social ontology could be further articulated in terms of Dewey's inclusive conceptualisation of the social. I will end by presenting two further reasons for considering a social ontology along the lines suggested above. Firstly, in distinguishing a pragmatist social ontology from conceptions of the social as sui generis, one would find support not only in Dewey's work but also in that of George Herbert Mead, a pragmatist thinker even more intimately linked to developments in the social interactionist tradition as conceived by Frega. In Mead's work (1934), as well as in that of Dewey, the concept of habit plays a central role and should be spelled out in terms of biological endowments and biophysical processes, as suggested also by Mead's concept "the biologic individual." ${ }^{27}$ In sociology, this part of Mead's legacy has largerly been left behind, probably because "most symbolic interactionists overlook the biological dimension in Mead's thought" (Cohen 2000: 87). Recovering this biological dimension may be taken as imperative in spelling out a pragmatist social ontology, particularly so since part of Mead's work is of a general philosophical nature ${ }^{28}$ and could serve as an important source, together with Dewey's work.

18 All exegetical considerations of classical pragmatism or pragmatists aside, however, there is another reason for taking Dewey's inclusive conceptualisation of the social into 
account. On Frega's interpretation, Dewey's conception of the public focuses on "human affectedness" (2019: 188) and on an "awareness of a shared affectedness" (2019: 359). In later chapters of his book he applies Dewey's conception in addressing global challenges and in thus considering "transnational publics brought to life by the awareness of a shared affectedness produced by the global reach of risks related to environment, security, health, social welfare" (2019: 359). Yet, the relevance of Dewey's concept, and hence of Frega's account of democracy, could be further enhanced by spelling out the notion of affectedness in terms of vulnerabilities and dependencies captured by Dewey's inclusive conceptualisation of the social. If specified in terms of biologically conditioned vulnerabilities and technologically conditioned dependencies, a shared affectedness regarding environmental risks and health risks in particular could become an even more central focus in a pragmatist account of democracy. That would in turn support the relevance of a pragmatist account in addressing current global challenges.

\section{BIBLIOGRAPHY}

ANDERSON Benedict, (1991 [1983]), Imagined Communities: Reflections on the Origin and Spread of Nationalism, revised and extended edition, London, Verso.

BULMER Martin, (1984), The Chicago School of Sociology: Institutionalization, Diversity, and the Rise of Sociological Research, Chicago, IL, University of Chicago Press.

CAMIc Charles, (1986), “The Matter of Habit,” American Journal of Sociology, 91 (5), 1039-87.

COHEN Ira J., (2000), "Theories of Action and Praxis," in Bryan S. Turner (ed.), The Blackwell Companion to Social Theory, Malden, Mass, Blackwell Publishers, 73-111.

DEEN Phillip, (2016), "Recontextualizing John Dewey's The Public and Its Problems," History of Political Thought, 37 (3), 509-29.

DEWEY John, (1928), "Social Philosophy," (Lecture Notes), Box 33, Folder 9, John Dewey papers, 1858-1970, Special Collections Research Center, Southern Illinois University, Carbondale.

DEWEY John, (1973), Lectures in China, 1919-1920, transl. and ed. R. W. Clopston and T.-C. Ou, Honolulu, The University of Honolulu Press. References to this work are indicated by LC followed by page numbers.

DEWEY John, (1976-1983), The Middle Works, 1899-1924, 15 volumes, ed. J. A. Boydston, Carbondale, IL, Southern Illinois University Press. Citations of items in this edition are indicated by MW followed by volume and page numbers.

DEWEY John, (1981-1992), The Later Works, 1925-1953, 17 volumes, ed. J. A. Boydston, Carbondale, IL, Southern Illinois University Press. Citations of items in this edition are indicated by LW followed by volume and page numbers.

DEWEY John, (2015), “Lectures in Social and Political Philosophy," European Journal of Pragmatism and American Philosophy, (7) 2,1-39. [journals.openedition.org/ejpap/404]. 
DURKHEIM Émile, (1982 [1895]), The Rules of Sociological Method, ed. Steven Lukes, trans. W. D. Halls, New York, NY, The Free Press.

FREGA Roberto, (2019), Pragmatism and the Wide View of Democracy, Cham, Palgrave Macmillan.

GIDDENS Anthony, (1984), The Constitution of Society: Outline of the Theory of Structuration, Cambridge, Polity Press.

HELMES-HAYES Richard C., (1987), “'A Dualistic Vision': Robert Ezra Park and the Classical Ecological Theory of Social Inequality," The Sociological Quarterly, 28 (3), 387-409.

MCDONALD Dennis W., (2011), “Beyond the Group: The Implications of Roderick D. McKenzie's Human Ecology for Reconceptualizing Society and the Social," Nature and Culture, 6 (3), 263-84. MCKENZIE Roderick Duncan, (1924), "The Ecological Approach to the Study of the Human Community," American Journal of Sociology, 30 (3), 287-301.

MEAD George Herbert, (1932), The Philosophy of the Present, ed. Arthur E. Murphy, La Salle, IL, Open Court.

MEAD George Herbert, (1934), Mind Self and Society from the Standpoint of a Social Behaviorist, ed. C. W. Morris. Chicago, University of Chicago.

MEAD Georg Herbert, (1938), The Philosophy of the Act, ed. Charles W. Morris, Chicago, University of Chicago Press.

MIDTGARDEN Torjus, (2019), “Dewey's Conceptualization of the Public as Polity Contextualized: The Struggle for Democratic Control over Natural Resources and Technology," Contemporary Pragmatism, 16 (1), 104-31.

PARK Robert E. \& Ernest W. BURGESS, (1921), Introduction to the Science of Sociology, Chicago, IL, The University of Chicago Press.

PARK Robert E., (1936), “Human Ecology,” American Journal of Sociology, 42 (1), 1-15.

SHILS Edward, (1948), The Present State of American Sociology, Glencoe, IL, Free Press.

TESTA Italo, (2016), “Dewey's Social Ontology: A Pragmatist Alternative to Searle's Approach to Social Reality," International Journal of Philosophical Studies, 25 (1), 40-62.

TILMAN Rick, (1998), “John Dewey as User and Critic of Thorstein Veblen's Ideas," Journal of the History of Economic Thought, 20 (2), 145-60.

TILMAN Rick \& Terry KNAPP, (1999), “John Dewey's unknown critique of Marginal Utility Doctrine: Instrumentalism, Motivation, and Values," Journal of the History of the Behavioral Sciences, 35 (4), 391-408.

WARFIELD RAWLS Anne, (1987), “The Interaction Order Sui Generis: Goffman's Contribution to Social Theory," Sociological Theory, 5 (2), 136-49.

WARFIELDS RAWLS Anne, (2009), “An Essay on Two Conceptions of Social Order: Constitutive Orders of Action, Objects and Identities vs Aggregated Orders of Individual Action," Journal of Classical Sociology, 9 (4), 500-20. 


\section{NOTES}

1. Dewey develops his inclusive conceptualisation of the social in the text to which Frega refers ("The Inclusive Philosophical Idea" [LW3: 41-54]) but also in his lectures on social and political philosophy during the years 1923-1928 (see footnote 12 below).

2. See MW9: 5-7.

3. See MW9: 8.

4. "By [language] we are led to share vicariously in past human experience, thus widening and enriching the experience of the present. We are enabled, symbolically and imaginatively, to anticipate situations. In countless ways, language condenses meanings that record social outcomes and presage social outlooks" (MW9: 43).

5. See MW9: 8. While Dewey later expresses his indebtedness to Mead (see LW12: 5), it is notable that Mead (1934: 79) makes reference to Dewey's most elaborate analysis of communication in chapter 5 of Experience and Nature.

6. See Park \& Burgess (1921: 36-8, 182-5).

7. For example, Edward Shils has argued that Park "could not formulate a dynamic theory of behavior which would have unified his own classificatory and descriptive scheme and helped to systematize his rich aphoristic insights into modern social structure" (Shils 1948: 10, cited in Bulmer 1984: 122-3). With regard to the Human Ecology framework outlined by Park and other members of the Chicago school, Richard C. Helmes-Hayes has pointedly summed up that, "while formidably broad and ambitious in its scope and enriched by a sensitive tradition of empirical investigation, [human ecology] is an approach whose theoretical reach exceeded its grasp" (1987: 397).

8. See Frega (2019: 80-3).

9. See Frega (2019: 65-78).

10. In particular, Dewey rejects behaviouristic and physicalistic reductionism regarding mental or social phenomena (see LW3: 45), or reduction of social and moral phenomena to biological phenomena (LW3: 52).

11. Dewey briefly considers how "physiological factors of sex, of procreation, immaturity and need of care" contribute to the organisation of the family (LW3: 48). He further suggests that social phenomena, or society at large, would be sustained by physical and technological infrastructures and by material artifacts: "land, including all the natural resources (and obstacles) and forms of energy for which the word 'land' stands [...] the tools and machines by which physical energies are utilized [...] physical appliances and apparatus, from clothes and houses to railways" (LW3: 47).

12. The important texts include "The Inclusive Philosophical Idea" (LW3: 41-54), "Syllabus: Social Institutions and the Study of Morals" (MW15: 230-72, in particular MW15: 247-69) and "Social Philosophy" (Dewey 1928). As Phillip Deen has pointed out (2016), the latter lecture notes outline a theoretical basis for Dewey's conception of the public.

13. See Frega (2019: 190n20).

14. One should also note, however, the distinct contribution of Park's student, Roderick Duncan McKenzie (1924). As Dennis McDonald has pointed out (2011), there are differences that need to be taken into account between Mc Kenzie's contribution, on the one hand, and that of Park and Burgess, on the other. In particular, McKenzie did not subscribe to "the sharp distinction between the ecological and the social that Park and Burgess maintained" (2011: 269). McKenzie rather held that "[s]ociety and the social encompass not only human-to-human relations, but also vital relations of humans to objects of nature and culture" (2011: 269).

15. "Competition is universal in the world of living things. Under ordinary circumstances it goes on unobserved even by the individuals who are most concerned" (Park \& Burgess 1921: 510). 
16. Dewey thus considers "[c]ertain physiological factors of sex, of procreation, immaturity and need of care" (LW3: 48). In TPIP he further brings out how childrens' immaturity and the fullfilment of their developmental potentials call for adequate conditions for care and education. "[T]he period in which education is possible to an effective degree is that of childhood; if this time is not taken advantage of the consequences are irreparable. The neglect can rarely be made up later" (LW2: 274). Hence, he stresses, child labour has irreparable and irretrievable consequences both for the child and for society (see LW2: 274 and also Dewey 1928).

17. See MW15: 249.

18. In his lecture notes from the same year (1928) Dewey more dynamically considers how natural, technological and artefactual environments are integrated in human production and consumption, and are constitutive elements of human development or "growth." Through production and consumption, he points out, there is "[d]emand for permanent possession of means that are means for many wants, not exhausted in consumption - for example [demand for] land, for money, for owning books, pictures [...] This want is met however not only by possession but by command whenever needed, streets/lights, lighthouses, schools [...] tools, instruments, appliances, machinery" (Dewey 1928).

19. See Midtgarden (2019) for an historical account of Dewey's concept of the public that focuses on his practical political support of regulatory policies in the late 1920s and the early 1930s.

20. See LW2: 274, 316, Dewey (1928).

21. Considering "the economic-industrial activities that affect the distribution of power, and of abilities, capacities, enjoyments" (MW15: 247), Dewey particularly notes how vulnerabilities and dependencies emerge through various modes of consumption (see MW15: 248-69, Dewey 1928).

22. See also LW3: 47 and LW11: 246.

23. See Rick Tilman (1998), Tilman \& Knapp (1999).

24. "To be right, [the claim] must be an acknowledged claim, having not the mere power of the claim-antclaimant behind it, but the emotional and intellectual assent of the community" (LW5: 285). In a more negative and critical perspective, Dewey in $D E$ observes how "[i]ndividuals use one another so as to get desired results, without reference to the emotional and intellectual disposition and consent of those used" (MW9: 8).

25. See also Dewey (2015: 37).

26. See MW15: 268-9.

27. See Mead (1934: 347-53).

28. See Mead $(1932,1938)$.

\section{AUTHOR}

\section{TORJUS MIDTGARDEN}

University of Bergen

Torjus.Midtgarden[at]uib.no 